42. SODHI, N., L.W. OLIPHANT, P.C. JAMES, and I.G. WARKINTIN. 1993. Merlin (Falco columbarius). In: A. Poole and F. Gill (eds.) The Birds of North America, no. 44. The Academy of Natural Sciences, Philadelphia, PA, and The American Ornithologists' Union, Washington, D.C.

43. SWAINSON, W., and J. RICHARDSON. 1831. Fauna-Boreali-Americana; or the Zoology of the Northern Parts of British America. Part Second, The Birds. John Murray, London, United Kingdom.

44. TAVERNER, P.A. 1919. The birds of Shoal Lake, Manitoba. Canadian Field-Naturalist 32: 137-144.

45. TAYLOR. P. 1983. Wings Along the Winnipeg: The Birds of the Pinawa-Lac du Bonnet Region, Manitoba. Manitoba Naturalists Society, Eco Series, no. 2.

46. TAYLOR, P. 1993. Mid-continental jaegers: a Manitoba perspective. Blue Jay 51: 157-164.
47. TAYLOR, P. 1997. A tale of two kittiwakes. Blue Jay 55: 149-151.

48. TAYLOR, P., B. SHETTLER, and C. BRADSHAW. 1997. Northern Parulas west of Lake Winnipeg. Blue Jay 55: 220-221.

49. TEMPLE, A.S. 1972. Systematics and evolution of the North American Merlins. A $\iota k$ 89: 325-338.

50. UNDERWOOD, T.J., and H.E. den HAAN. 2000. Checklist of the Birds of Delta Marsh, $3^{\text {rd }}$ edition. [Delta Marsh Bird Observatory.]

51. WEINTRAUB, J.D., and M. SAN MIGUEL. 1999. First record of the Ivory Gull in California. Western Birds 30: 39-43.

52. ZINK, R.M. 2004. The role of subspecies in obscuring avian biological diversity and misleading conservation policy. Proceedings of the Royal Society London, Series B 271: 561-564.

\title{
SEARCHING FOR EDWARD CALCUTT
}

\section{STUART HOUSTON and MARY I. HOUSTON, 863 University Drive, Saskatoon, SK S7N 0J8.}

Our story begins with Wells W. Cooke, North America's leading investigator of bird migration during the final two decades of the 19 th century. Cooke began collecting early spring migration dates, beginning with 13 observers in eight states in 1882, and 26 observers in 1883 . From these he calculated that birds traveled an average of 23 miles per day. Concentrating particularly on the Mississippi River valley, he was joined by three Manitoba observers in 1884 and another three in 1885 , the latter including for the first time, Edward Calcutt. Calcutt lived just east of the Saskatchewan-Manitoba boundary near "Shell River post office," 1 and a mile east of Minniska post office which was established in 1890 (8 km north of present Russell). Copies of Calcutt's 1885 migration dates were made available to Ernest Thompson [Seton] when he published Birds of Manitoba in $1891 .^{4}$

In 1975, when we began updating the Yorkton area bird records, we realized that the Calcutt records from Shell River might fall near the Saskatchewan boundary. At our request, Chan Robbins at the Patuxent Wildlife Research Center in Laurel, Maryland, sent us copies of the Calcutt records and correspondence. From these we learned that the Calcutt homestead was ten miles east of the Saskatchewan boundary, on section 26-21-28 WPM (west of the principal meridian or W1). Calcutt had, for those times, dates for an unusually large list of species (130).

\section{Calcutt's Migration Dates}

Since Calcutt was a farmer working outdoors much of the day, with bush and a small lake visible from his house (Figure 1), most species should have been recorded on the day they arrived. Those interested in climatic change will note that most species in the accompanying table, especially the earliest arrivals, came later in the spring than they do now over one century later.

Calcutt used many species names that are no longer familiar, but added marginal notes 


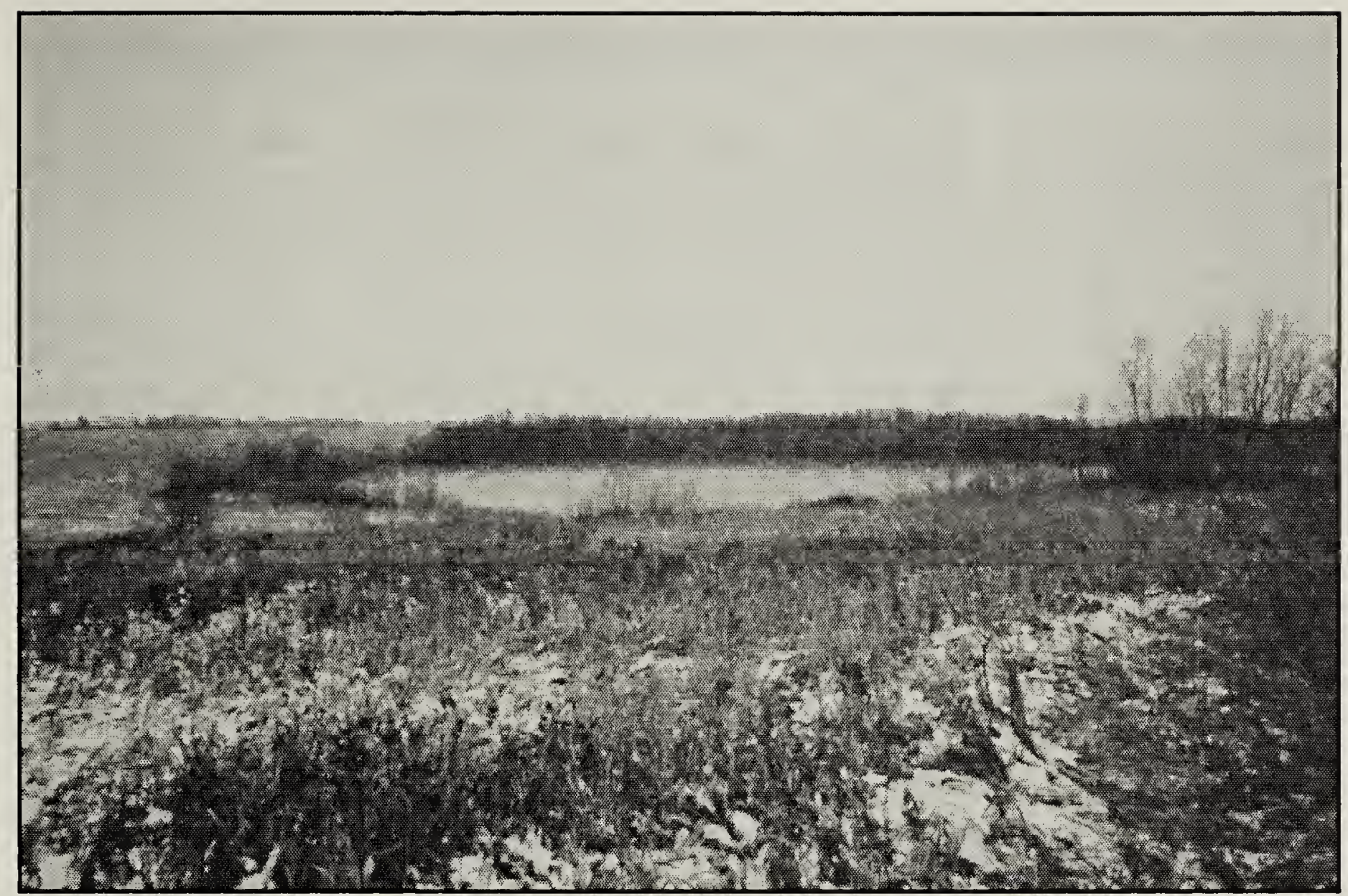

Figure 1. Calcutt Lake

Mary Houston

giving descriptions of features for perplexing species. Using his notes and several references for checking old names, we have assigned current names to many of Calcutt's species in Table $1 .^{3.4}$ Species readily identified were yellow-bird for Yellow Warbler, cherry-bird for Cedar Waxwing, and yellow-headed warbler for the Chestnutsided Warbler. In early spring the "Longspur Lark" was the Lapland Longspur. In the prairie provinces, the "hen hawk' was either the Red-tailed or Swainson's but the date and location left little doubt that it was the former. The "Prairie Hawk" was the Northern Harrier. We were initially confused by Calcutt's use of the term "flycatcher" to include all warblers. The term "sanderling" might have included any of the "peeps." Birds not identified are listed for each of the three years at the bottom of Table 1 .

Records of greatest interest were a pair of Whooping Cranes on April 30, 1885, and another pair on April 16, 1890. As elsewhere, Cliff Swallows built on buildings immediately, whereas Barn Swallows and Purple Martins remained only "transients" through 1885. Before Mourning Doves had spread this far west, the five "wild pigeons" on June 15, 1885 were almost certainly Passenger Pigeons, as Seton assigned them; none was sighted in 1890 or 1891 . The pallid northern subspecies of the Horned Lark, destined for the Arctic tundra, came through in numbers in late May.

Some easy-to-identify large species were not reported in any of the three years: American White Pelican, swan, Great Blue Heron, and Snowy Owl. Neither species of bluebird was reported. By 1890, Calcutt had either learned to identify, or perhaps saw for the first time: Ruddy Turnstone; Willet; Wilson's Thrush or Veery; Olive-backed or Swainson's Thrush; Orange-crowned Warbler; Savannah Sparrow; Chestnutcollared Longspur.

\section{Our 2003 visit}

We had a chance to visit the Calcutt homestead on October 26, 2003. Gary Halwas, who lives on the southeast quarter of section 26, directed us across his harvested stubble to the remains of a basement excavation on a tongue of treed land overlooking Calcutt Lake. He had not heard 
TABLE 1. MIGRATION DATES for 130 species, MINNISKA, MANITOBA, 1885-1891

\section{Species Name}

Greater White-fronted Goose

Snow Goose

Canada Goose

Brant?

American Wigeon

Mallard

Blue-winged Teal

Northern Shoveler

Northern Pintail

Green-winged Teal

Canvasback

Redhead

Lesser Scaup

White-winged Scoter

Bufflehead

Common Goldeneye

Hooded Merganser

Common/Red-breasted Merganser

Ruddy Duck

Sharp-tailed Grouse

Common Loon

Homed Grebe?

Red-necked Grebe?

Western Grebe?

Double-crested Cormorant

American Bittern

Black-crowned Night-Heron

Turkey Vulture

Osprey

Bald Eagle

Northem Harnier

Sharp-shinned Hawk

Red-tailed Hawk

Golden Eagle

American Kestrel

Peregrine Falcon

Virginia Rail

Sora

American Coot

Sandhill Crane

Whooping Crane

Black-bellied Plover

American Golden-plover?

Killdeer

Greater Yellowlegs

Lesser Yellowlegs

Solitary Sandpiper

Willet

Spotted Sandpiper
Name or description given by Calcutt

Large Grey Wild Goose

Wavey or Snow Goose

Canada Wild Goose, five goslings in 1891

Brant Goose

Widgeon Duck or Bald Pate Duck

Mallard Duck

Blue Winged Teal Duck

Spoon Bill Duck

Pin Tail Duck

Golden or Green Winged Teal Duck

Canvas Back Duck

Red Head Duck

Blue Bill Duck

Sea Duck with white stripe on wing

Buffle Head or Butter Duck

Golden Eye or Whistler Duck

Mouming Duck or Hooded Merganser

Shelduck Duck

Fan Tail or Dun Duck, white face patch

Common Sharp Tail Grouse

Northern Loon or Northem or Great Diver

Common Grebe or Hell Diver

Large Grebe

Hooded Grebe

Common Cormorant or Crow Duck

Common American Bittem

Common Night Heron

Turkey Vulture

Fish Hawk

Bald Eagle

Prairie or Marsh Hawk; Harrier Blue Hawk

Sharp Shinned Hawk

Hen Hawk

Golden Eagle

Sparrow Hawk

Duck Hawk

Virginia Rail

Water or Common Rail, short yellow bill

Water Hen; nest, 13 eggs, 1885

Sand Hill Crane

White Crane, black wing tips

Black Belly Field Plover

Black Bellie Field or Golden Plover

Kill Deer Plover

Large Yellow Shank

2nd size Yellow Shank

Solitary Sandpiper Plover

Willet Plover

Common Sandpiper, breeds here

$\begin{array}{llllll}\text { 1885\# } & & \text { 1890\# } & & \text { 1891\# } & \\ \text { Apr10 } & 18 & \text { Apr11 } & 2 & \text { Apr12 } & 6 \\ & & \text { May20 } & 8 & & \\ \text { Apr9 } & 15 & \text { Apr2 } & 2 & \text { Mar28 } & 1 \\ & & \text { Apr 18 } & 30 & \text { Apr28 } & 25 \\ \text { May 12 } & 2 & \text { Apr20 } & 19 & \text { Apr23 } & 7 \\ \text { Apr6 } & 12 & \text { Apr 13 } & 2 & \text { Apr7 } & 2 \\ \text { May2 } & 2 & \text { Apr 18 } & 4 & \text { Apr25 } & 6 \\ \text { May8 } & 2 & \text { Apr24 } & 7 & \text { Apr20 } & 7 \\ \text { Apr20 } & 4 & \text { Apr20 } & 22 & & \\ \text { May2 } & 2 & \text { Apr17 } & 9 & \text { Apr20 } & 8 \\ \text { Apr24 } & 4 & \text { Apr20 } & 4 & \text { Apr22 } & 8 \\ \text { May3 } & 2 & \text { Apr20 } & 16 & \text { Apr22 } & 15 \\ \text { May1 } & 2 & \text { Apr17 } & 20 & \text { Apr10 } & 21 \\ \text { May 12 } & 1 & \text { May23 } & 2 & \text { May23 } & 6 \\ \text { Apr27 } & 2 & \text { Apr21 } & 4 & \text { Apr21 } & 12 \\ \text { Apr28 } & 1 & \text { Apr20 } & 2 & \text { Apr21 } & 3 \\ \text { May 11 } & 8 & \text { Apr28 } & 2 & \text { Apr28 } & 6 \\ & & \text { May3 } & 2 & & \\ \text { May23 } & 1 & \text { Jun2 } & 8 & \text { Apr26 } & 21 \\ & & \text { winter } & & & \end{array}$

$\begin{array}{llllll}\text { May4 } 2 & \text { Apr } 19 & 2 & \text { Apr21 } & 12\end{array}$

May3 2 May 12

May 132 Apr 281

May 112 May $15 \quad 7$ May 19

May $13 \quad 4 \quad$ May $29 \quad 18$ May 204

May $4 \quad$ Apr $29 \quad 2$

May $16 \quad 1$

Apr25 $2 \quad$ May21 4

$\begin{array}{llll}\text { Apr } 4 & 2 & \text { Apr } 12 & 1\end{array}$

Apr9 2

Apr 42

May 101

Apr5 1 Apr3 1

May $22 \quad 2$ Apr $15 \quad 1$

$\begin{array}{llllll}\text { Apr } 14 & 1 & \text { Apr3 } 1 & \text { Apr22 } & 1\end{array}$

Apr 82

Jun $6 \quad 1$

May 122 May 212 May 202

$\begin{array}{llll}\text { May } 12 & 2 & \operatorname{Jun} 7 & 6\end{array}$

$\begin{array}{llllll}\text { Apr } 19 & 2 & \text { Apr } 15 & 3 & \text { Apr } 14 & 2\end{array}$

Apr30 2 Apr 162

May $16 \quad 30 \quad$ May $19 \quad 40$

May $2650 \quad$ May 161

$\begin{array}{llllll}\text { Apr6 } & 1 & \text { Apr7 } & 1 & \text { Apr } 11 & 2\end{array}$

$\begin{array}{llll}\text { Apr24 } & 7 & \text { Apr } 14 & 2\end{array}$

$\begin{array}{llllll}\text { Apr } 24 & 3 & \text { Apr } 15 & 7 & \text { May } 9 & 7\end{array}$

May 311

May 312 


\begin{tabular}{|c|c|c|c|c|c|c|c|}
\hline Upland Sandpiper & Prairie Plover, peculiar call & May 4 & 2 & May 11 & 4 & May 20 & 4 \\
\hline Long-billed Curlew & Long-billed Curlew, rare here & & & Jun 7 & 3 & & \\
\hline Ruddy Turnstone & Turnstone Plover & & & May 15 & 2 & May 10 & 2 \\
\hline Sanderling? & small sanderling plover & & & & & May 19 & 35 \\
\hline Wilson's Snipe & English Snipe & May 4 & 1 & Apr 16 & 3 & Apr 18 & 2 \\
\hline Phalarope & Lake or Swimming Plover & & & May 16 & 15 & & \\
\hline Franklin's Gull? & Black Head Small Gull & Apr 24 & 2 & Apr 25 & 2 & Apr 15 & 3 \\
\hline Herring Gull? & largest gull & & & May 4 & 1 & Apr 19 & 1 \\
\hline Black Tern & Small Blue Tern, black breast, Keask & May 18 & 11 & May 25 & 18 & May 24 & 23 \\
\hline Passenger Pigeon & Wild Pigeon; ETS & Jun 15 & 5 & & & & \\
\hline Black-billed Cuckoo & Black-billed Cuckoo & Jun 16 & 2 & Jun 8 & 2 & Jun 1 & 1 \\
\hline Great Horned Owl & Great Horned Owl & winter & & Apr 2 & 2 & & \\
\hline Barred Owl & Barred Owl & & & Jun 8 & 1 & & \\
\hline Long-eared OWl & Long Eared Owl & & & & & May 21 & 2 \\
\hline Common Nighthawk & Night Hawk & May 24 & 1 & May 27 & 1 & May 26 & 4 \\
\hline Whip-poor-will & Whip Poor Will; stayed until August & Jun 20 & 1 & & & & \\
\hline Ruby-throated Hummingbird & Common Green Humming Bird & Jun 3 & 1 & May 31 & 1 & May 21 & 1 \\
\hline Belted Kingfisher & Kingfisher & May 1 & 1 & & & & \\
\hline Yellow-bellied Sapsucker & Red Head and Throat Striped Woodpecker & May 3 & 2 & & & & \\
\hline Downy Woodpecker? & Red-naped Small Striped Wood Pecker & winter & & Apr2 & 1 & Apr 2 & 2 \\
\hline Northern Flicker & High Holder or Golden Wood Pecker & Apr 27 & 2 & Apr 16 & 2 & Apr 20 & 2 \\
\hline (Western?) Wood-pewee & Wood Pewee & & & Jun 9 & 2 & May 23 & 1 \\
\hline Eastern Kingbird & King Bird & May 21 & 1 & May 24 & 7 & May 21 & 2 \\
\hline Loggerhead Shrike & Northern Shrike, breeds & & & & & May 12 & 2 \\
\hline Northern Shrike & Butcher Bird or Northern Shrike & Mar 14 & 1 & Apr 8 & 2 & & \\
\hline Red-eyed Vireo? & olive-green, white breast, sings constantly & Jun 8 & 2 & & & & \\
\hline Gray Jay & Labrador or Hudson Bay Jay & winter & & Apr 1 & 2 & & \\
\hline Blue Jay & Blue Jay, on and off all winter, $1890-91$ & May 15 & 2 & & & Apr 1 & 7 \\
\hline Black-billed Magpie & American Magpie & & & Apr 8 & 1 & & \\
\hline American Crow & Crow or Common Crow & Apr 3 & 5 & Apr 1 & 4 & Arp 1 & 2 \\
\hline Common Raven & Common Raven & & & Apr 3 & 2 & & \\
\hline Horned Lark & Horned or Shore Lark, pallid & May 23 & 50 & Apr 1 & 6 & May 21 & 31 \\
\hline Purple Martin & Purple Martin & May 23 & 1 & May 22 & 4 & May 25 & 2 \\
\hline Tree Swallow & Tree Swallow & & & May 1 & 20 & & \\
\hline Bank Swallow & Bank Swallow & Apr 30 & 17 & & & Apr 26 & 19 \\
\hline Cliff Swallow & House or Mud or Cliff Swallow & May 23 & 18 & May 23 & 5 & May 25 & 7 \\
\hline Barn Swallow & Barn Swallow, forked tail & May 30 & 4 & & & & \\
\hline Black-capped Chickadee & Chick A Dee & winter & & & & & \\
\hline House Wren & House Wren & May 17 & 2 & Jun 1 & 2 & May 20 & 2 \\
\hline Marsh Wren & March Wren & & & Jun 5 & 4 & & \\
\hline Veery & Wilson's Thrush & & & Apr 19 & 1 & May 21 & 2 \\
\hline Swainson's Thrush & Solitary Thrush or Olive-backed Thrush & Apr 30 & 2 & May 31 & 4 & & \\
\hline Hermit Thrush & Solitary Thrush or Hermit Thrush & Apr 18 & 2 & Apr 21 & 1 & May 13 & 3 \\
\hline American Robin & Robin & Apr 13 & 2 & Apr 7 & 1 & Apr 13 & 5 \\
\hline Gray Catbird & Cat Bird & May 18 & 1 & May 26 & 2 & May 22 & 2 \\
\hline Brown Thrasher & Brown Thrasher Thrush or Long-tailed Thrush & May 23 & 1 & Jun 4 & 2 & & \\
\hline Cedar Waxwing & Cherry Bird & Jun 5 & 5 & May 30 & 21 & May 22 & 7 \\
\hline Orange-crowned Warbler & Orange Crowned Warbler & & & May 31 & 2 & & \\
\hline Yellow Warbler & Common Yellow Bird & May 15 & 3 & May 29 & 4 & May 20 & 3 \\
\hline Chestnut-sided Warbler & Yellow Crowned Warbler & & & Jun 4 & 3 & & \\
\hline Yellow-rumped Warbler & Striped or Yellow-rumped Flycatcher & Apr 30 & 19 & Apr 27 & 2 & & \\
\hline American Redstart & Small Orange and Black Flycatcher & May 24 & 2 & & & & \\
\hline Eastern Towhee & Towhee Bunting & & & & & May 8 & 1 \\
\hline
\end{tabular}


American Tree Sparrow

Chipping Sparrow

Clay-colored Sparrow

Vesper Sparrow

Savannah Sparrow

Song Sparrow

White-throated Sparrow

Harris's Sparrow

Dark-eyed Junco

Lapland Longspur

Chestnut-collared Longspur

Snow Bunting

Rose-breasted Grosbeak

Bobolink

Red-winged Blackbird

Western Meadowlark

Yellow-headed Blackbird

Rusty Blackbird

Brewer's Blackbird

Common Grackle

Brown-headed Cowbird

Baltimore Oriole

Pine Grosbeak

Purple Finch?

White-winged Crossbill

Common Redpoll

American Goldfinch

Evening Grosbeak
Sparrow, White Wing Bar, breast spot, red pol Apr 10

Common Chipping Sparrow

Small Grey Bird; nest 4 eggs, 1985; ETS

Sparrow, white tail feathers

Savanna Sparrow

Song Sparrow

Sparrow, yellow spot over eye, ETS

Bull Finch or Black Head Sparrow

Slate-coloured Snow Bird

Longspur Lark

Chestnut Longspur

Snow Bird or Bunting

Rose Breasted Gross Beak

Rice Bird or Bobolin; nest, 6 eggs, 1885

Red-shouldered Black Bird

Meadow Lark

Yellow Head Black Bird

Rusty Black Bird

Brewer's Black Bird

Crow or Bronzed Black Bird

Cow Bunting

Baltimore Oriole

Pine Gross Beak, last seen, Apr 12/90

Red or Scarlet Finch; ETS

White Wing Cross Bill

Red Polled Linnet; last seen, Mar 21/90

Thistle Bird or American Gold Finch

Gros Beak, yellow
May 189

$\begin{array}{llllll}\text { Apr29 } 2 & \text { May } 1 \quad 6 & \text { Apr } 29 & 3\end{array}$

Apr 301

Apr 18 $5 \quad$ Apr19 5 Apr23 2

$\begin{array}{llll}\text { May } 6 & 2 & \text { Apr } 27 & 14\end{array}$

May 153 May 41 Apr 13

$\begin{array}{lllll}\text { Apr } 81 & 1 & \text { Apr } 4 & 1 & \text { Apr } 8 \\ \end{array}$

Mar 287

May 313

winter winter

May $161 \quad$ May 232

May $18 \quad 1 \quad$ May $18 \quad 3 \quad$ May 182

$\begin{array}{llllll}\text { Apr } 13 & 31 & \text { Apr 13 } & 3 & \text { Apr } 15 & 5\end{array}$

$\begin{array}{llllll}\text { Apr } 12 & 1 & \text { Apr } 12 & 2 & \text { Apr } 7 & 1\end{array}$

May 11 Apr22 5 May $8 \quad 13$

Apr $18 \quad 18$ Apr $16 \quad 10$

Apr $16 \quad 20$

$\begin{array}{llllll}\text { Apr } 15 \quad 17 & \text { Apr 18 } 11 & \text { Apr } 16 \quad 9\end{array}$

May 145 May 123 May 109

May 161 May 292

winter winter

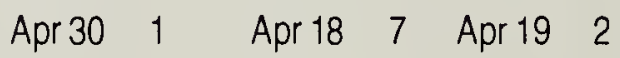

Mar 201

winter

May 241 Jun 32 May 241

Feb 20

Notes: ? after the name in left column indicates that identification is only probable.

ETS - identification corroborated by Ernest Thompson Seton, Birds of Manitoba, citing Calcutt's 1885 dates only.

Keask - a Cree name listed by Calcutt.

\section{UNIDENTIFIED SPECIES (1885)}

Black or Dark Brown Eagles, 2 on Apr 25, classed by ETS as Turkey Vultures.

"Very small dark grey" winter owl might have been a Boreal, too small for Northern Hawk-Owl, too grey for Saw-whet?

"Wood Thrush" - ERROR IN NAME - another hand (W.W. Cooke?) wrote: "probably Hermit".

"Solitary or Hermit Thrush" - another hand (WWC?) wrote: "probably Olive-backed". Solitary then meant Hermit Thrush.

"Greenish-yellow Flycatcher" with small white bars on wings = warbler. Could be Tennessee, Blackpoll or Pine Warbler

"Sandpiper Plover," 2 on May 25.

\section{UNIDENTIFIED SPECIES (1890)}

flycatcher = warbler, "striped \& blue" 3 on April 18, too early for Canada, too far west for Cerulean, so probably Yellow-rumped "Olive-backed Flycatcher," 2 on June 5, might have been correctly identified - if not a warbler.

\section{UNIDENTIFIED SPECIES (1891)}

"Curlew Plover," 5 on May 15.

"Yellow-bellied Flycatcher," 5 on May 12, might have been correctly identified - if not a warbler. 
of the name Calcutt, but later his friend Willis Kieper informed us that the lake on this section was known as Calcutt Lake. Calcutt had described this situation as follows in his letter to Cooke on February 7, 1885 in which he accepted Cooke's invitation to send spring migration records that year: "On my place there is a large bluff of poplar woods and a lake in front of the house of over ninety acres, and more birds visit this bluff than any other place in the county."

Calcutt's June 25 letter, which accompanied Calcutt's mailing of his first year of migration records, described the spring weather in 1885. "It has been a very unfavourable spring. ... The weather was so very cold and backward." However, he guessed that he had "not missed any birds unless a kinglet."

On our return to Saskatoon, we contacted the Manitoba Archives for Calcutt's homestead records. We expected four to ten pages of information, but to our surprise, Idelle Talbot, research assistant in Winnipeg, responded with photocopies of 120 pages. And what an interesting story they revealed! Calcutt was 53 years old when, on May 28, 1880, he arrived in western Manitoba, with his wife, Harriet, and their two sons, William and Albert. This was before homestead entries were available and he picked what he thought was suitable land, on what the surveyor later designated 26-21-29 WPM and "squatted" there. He had "pitched upon a nice situation, not knowing what land it was, but proved to be Hudson's Bay Co." Calcutt named it Lake View Farm.

Calcutt built a log house in November 1880. In March, 1883, he borrowed money and purchased section 35, due north of him, for $\$ 2$ per acre. The south or adjacent half was for William and the north half was for his son, Albert, then farming near Owen Sound, Ontario. By July 1885, the year before the railway reached Russell (which was four miles south and two miles west), Edward Calcutt had a log stable 16 x 24 feet and a $\log$ granary $20 \times 20$. Acres under cultivation on the northeast quarter were: 8 in 1881,12 in 1882 and 1883 , and 24 acres in 1884 .

The Calcutt occupancy of the northeast quarter of section 26 became legal on May 4, 1886, when letters patent were issued. However, it required more than another eleven years to obtain title to the adjacent northwest quarter, with about 100 pages of correspondence between Ottawa, Winnipeg, the land office at Birtle, and the Hudson's Bay Company (HBC) throughout most of this period. As Mrs. Harriet Calcutt explained in her letter to Mr. H.H. Smith, Commissioner of Dominion Lands, Winnipeg, on Aug 28, 1893, "We built our house and stables before the surveyors came $\&$ found our house was just on the line dividing the N.E. and N.W., our stable \& granary on the latter quarter ...Our N.E. quarter has only 144 acres, 15 of it being in the lake... As squatters of nearly 13 years residence ... all this has worried me greatly very few settlers are coming into this part there is no money in farming, but simply a living - plenty of abandoned farms laying around." The fur trading company agreed to relinquish its title, in return for equally suitable land elsewhere. After much correspondence, the $\mathrm{HBC}$ finally accepted as a fair trade, NE 28-31-10w2, north and east of the later village site of Tuffnell, Saskatchewan.

On April 16, 1897, Calcutt's possessions were listed: a concrete house, $20 \times 24$ feet (built in 1887), shingled, one floor, with cellar, valued at $\$ 250$; three log stables, a log granary, a hen house and root house, with these additional buildings valued, with the well, at $\$ 260$ (based on the Homestead Inspector Report \#914). The garden occupied half an acre and 50 acres were now under cultivation. Stock consisted of 20 cattle and three horses. The applied-for northwest quarter consisted of 90 acres of rough scrub land and hillside, none of it, other than the garden, fit for cultivation, and 70 acres of lake. 
The final entry in the homestead file was for April 5, 1902, when Calcutt was 75 years old. His lawyers in Winnipeg wrote to enquire on his behalf whether patent could be obtained for "that portion of the land which was covered by the water." We don't know when Calcutt died. "Mrs. Calcutt," probably Harriet, purchased a burial plot in 1901. We do know that Albert E. Calcutt, Edward's son, then "squatting" without title on NW 14-22-27, five miles east and three miles south of the future site of the town of Inglis, near the western boundary of Riding Mountain National Park, witnessed his father's signature in May 1897. Albert died in Russell on September 17, 1897, at age 44, after a brief .illness, ${ }^{2}$ and is buried in the cemetery there. There are no tombstones on any of the three Calcutt plots.

1. COOKE, W.W. 1888. Bird Migration in the Mississippi Valley, 1884-1885. U. S. Dept. Of Agriculture Div. Economic Ornithology Bull. \#2.

2. RUSSELL CHRONICLE AND FREE TRADE ADVOCATE, September 25, 1897 (microfilm).

3. SAYRE, J.K. 1996. North American Bird Folknames and Names. Foster City, CA: Bottlebrush Press.

4. THOMPSON, E.T. [Seton]. 1891. The birds of Manitoba. Proc. U.S. National Museum 13:457-643.

"There is much good land in the valley from the Fishing Lakes to the Assiniboine, but as it is flooded every spring, it is questionable whether it will ever be of much importance. For ten miles up there is an abundance of timber consisting of aspens, balsam-poplars, elm, black ash, oak, birch and sugar maple....In this wooded part the birds are innumerable. Kingfishers, blue jays, and Canada jays, catbirds, and American magpies, flitted from tree to tree uttering their discordant notes. Cherry-birds and pigeons were calmly and listlessly perched on the dense trees, having eaten plentifully of their favourite fruits, while the tyrant flycatcher, when alone or with some companions, chased and worried the crows, ravens, hawks, and eagles who tried in vain to escape from them. The beautiful white-bellied swallow swiftly skimming the surface of the river, helped in addition to enliven the valley."

"The Birch Hills form the dividing ridge between the water which flows into the main

Saskatchewan and the Assiniboine, or Red Deer and Swan Rivers. The remarkable profusion of flowers gives extraordinary beauty to large open areas; they generally occur in parterres of several acres in extent occupied by one species, here the yarrow, there the

fireweed, then a field of a species of helianthus, followed by Liatris scariosa. When viewed from an eminence, the country appeared to be clothed with pink, white, yellow, and blue, in singular contrast to the uniform tint that prevails on the great prairies of the Little Souris."

Henry Youle Hind, Narrative of the Canadian Red River Exploring Expedition of 1857 and of the Assiniboine and Saskatchewan Exploring Expedition of 1858, p.378 and 406 . 